\title{
BACTERIOPLANKTON FEATURES AND ITS RELATIONS WITH DOC CHARACTERISTICS AND OTHER LIMNOLOGICAL VARIABLES IN PARANÁ RIVER FLOODPLAIN ENVIRONMENTS (PR/MS-BRAZIL)
}

\author{
Mariana Carolina Teixeira ${ }^{1 *}$, Natália Fernanda Santana ${ }^{1}$, Júlio César Rodrigues de Azevedo ${ }^{2}$, Thomaz Aurélio Pagioro ${ }^{1,2}$ \\ ${ }^{1}$ Universidade Estadual de Maringá, Nupelia, Maringá, PR, Brasil; ${ }^{2}$ Universidade Tecnológica Federal do Paraná, Curitiba, PR, \\ Brasil.
}

Submitted: September 10, 2010; Returned to authors for corrections: September 20, 2010; Approved: January $31,2011$.

\begin{abstract}
Since the introduction of the Microbial Loop concept, many studies aimed to explain the role of bacterioplankton and dissolved organic carbon (DOC) in aquatic ecosystems. Paraná River floodplain system is a very complex environment where these subjects were little explored. The aim of this work was to characterize bacterial community in terms of density, biomass and biovolume in some water bodies of this floodplain and to verify its temporal variation and its relation with some limnological variables, including some indicators of DOC quality, obtained through Ultraviolet-visible (UV-VIS) and fluorescence spectroscopic analysis. Bacterial density, biomass and biovolume are similar to those from other freshwater environments and both density and biomass were higher in the period with less rain. The limnological and spectroscopic features that showed any relation with bacterioplankton were the concentrations of N-NH${ }_{4}$ and $\mathrm{P}_{-} \mathrm{PO}_{4}$, water transparency, and some indicators of DOC quality and origin. The analysis of these relations showed a possible competition between bacterioplankton and phytoplankton for inorganic nutrients and that the DOC used by bacterioplankton is labile and probably from aquatic macrophytes.
\end{abstract}

Key words: DOC, spectroscopy, bacterioplankton, floodplain.

\section{INTRODUCTION}

According to Cotner and Bidanda (18), the main factor influencing the relative importance of the microbial loop in aquatic environments is their trophic state. In oligotrophic environments the energy flux through microbial loop tends to be greater than through the conventional food chain, because the heterotrophic prokaryotes prosper even in low nutrients concentration (18). In eutrophic systems, Gasol and Duarte
(28) consider that there is low dissolved carbon availability for bacterial growth, due to a minor release of exudates by phytoplankton. However, Daniel et al. (21) showed that in the absence of recent algal carbon the microbial loop keeps transferring energy to metazooplankton. Regarding the carbon from aquatic macrophytes decomposition, it is estimated that around $24 \%$ can be converted to microorganisms' biomass (10). These pieces of information lead to the importance of carbon quality determining microbial loop role in an

*Corresponding Author. Mailing address: Universidade Estadual de Maringá, Nupelia, Av. Colombo, 5790 - Bloco G90 - CEP $87020-900$ - Maringá - PR Brasil.; E-mail: m_c_teixeira@yahoo.com 
ecosystem.

Variations in bacterioplankton densities are hardly related directly to trophic state. According to Toolan et al. (54) and Morris and Lewis (36) bacterioplankton density in oligotrophic systems is controlled by the low nutrients availability. In eutrophic systems some authors $(18 ; 28)$ consider bacterivory and viral death the main factors controlling density. Competition between bacterioplankton and phytoplankton is also discussed as a density controlling factor for bacteria, being mainly related to differences in phosphorous uptake and usage efficiency $(19 ; 20 ; 36 ; 40 ; 54)$.

The dissolved organic carbon (DOC) availability to heterotrophic bacteria depends on its biochemical composition, molecular size and inorganic nutrients concentration, among other factors (2). DOC from primary producer's exudates and senescence or from the excretes and death of other organisms is considered to be labile and readily available for bacterial consumption $(8 ; 11)$. Compounds of pedogenic origin, i.e., formed in the soil, like most of humic substances (HS), are considered biorefractory $(32 ; 37)$. The difference between the utilization of these fractions can lead to differences in the bacterial community with respect to composition, activity and other aspects.

Since the introduction of the microbial loop concept, many studies aimed to reveal the role of bacterioplankton and of DOC in aquatic environments, (eg. 17; 18;48; 51; 55), including in tropical ecosystems (eg. 22; 23; 25; 26; 44). In flooded areas, there are some studies in the Amazon floodplain (AM-Brazil) (e.g. 1; 2; 26; 37). In the upper Paraná River floodplain, Carvalho et al. (14) evaluated the factors that influence the abundance of bacterioplankton in 20 lagoons. However, so far, no study has related DOC quantity and quality with bacterioplankton features in these environments.

The upper Paraná River floodplain is a complex environment, made up of many water bodies, including rivers, small channels and connected and isolated lakes. The hydrologic pulses are considered the main factor determining the characteristics of the floodplain environments, and they have been receiving influences from the water flow regulation by the upstream chain of reservoirs (42). The floods increase similarity among environments during high water periods while during low water periods the habitats are more influenced by local forces (53).

The aim of this study was to characterize the bacterial community in terms of density, biomass and biovolume in some environments of the upper Paraná River floodplain and to observe seasonal (dry/rainy periods) variation of these features in a year without significant flood. Besides, the relation between bacterioplankton features and some limnological characteristics was investigated, including DOC quality indicators, which were estimated through ultra-violet and visible (UV-VIS) and fluorescence spectroscopic analysis.

\section{METHODS}

The water samples were obtained from six habitats of the floodplain (Fig. 1): Garças, Patos and Ventura lagoons, which are permanently connected to the main rivers of the floodplain, Paraná, Ivinheima and Baia, respectively; and Osmar, Fechada and Guaraná lagoons, which only receive water directly from the main rivers (Paraná, Ivinheima and Baia, respectively) during extremely high-water periods, remaining unconnected most part of the year. These are all shallow lagoons, with mean depths between 1 and $3.5 \mathrm{~m}$. The hydrometric level of Paraná River varied between 2.5 and $3.2 \mathrm{~m}$ (mean value of the six preceding days to sampling, according to Thomaz et al. (52)). The precipitation was also considered in this study, for it is an important factor in the floodplain, especially in the absence of great floods (42).

Samplings occurred every three months from November 2007 to September 2008 (hereafter NOV_07, FEB_08, JUN_08 and SEP_08). Samples were taken from subsurface, middle water column and about $0.5 \mathrm{~m}$ above maximum depth, in triplicates, with a resulting number of samples of 210 (in two 
occasions it was not possible to collect bottom samples due to the low depth of Osmar lagoon, c. $0.6 \mathrm{~m})$. Because no differences were detected among different depths (ANOVA) and also considering previous works that show these environments are too shallow to have significant differences among depths (eg. 41), data from the three depths were considered as replicates. Summarizing, we had: Garças (LGAR, $\mathrm{n}=36$ ); Osmar (LOSM, n = 30); Patos (LPAT, $\mathrm{n}=$ 36); Ventura (LVEN, $\mathrm{n}=36$ ); Fechada (LFEC, $\mathrm{n}=36$ ); Guaraná (LGUA, n = 36).

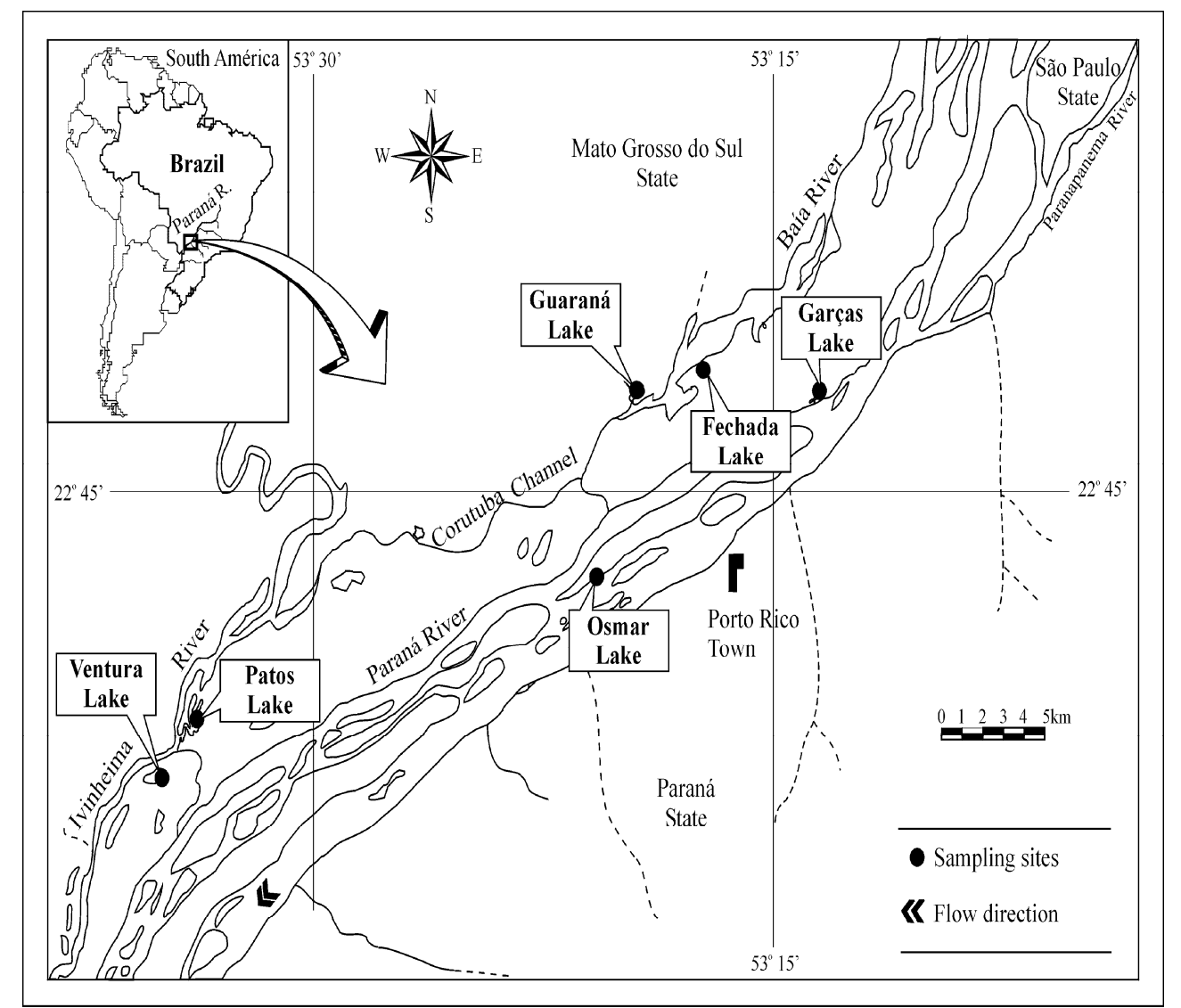

Figure 1. Map of the upper Paraná River floodplain. Black dots indicate sampling sites.

All water samples were obtained with a Van Dorn bottle in three points of the pelagic zone of each lagoon. The samples were immediately analyzed for $\mathrm{pH}$ and conductivity (Cond.) (Digimed DM2/DM3), dissolved oxygen (DO) and water temperature (YSI 55) and total alkalinity (Gran method, 12). Water transparency was measured with a Secchi disk. Back in the University of Maringá field station all samples were filtered in $0.45 \mu \mathrm{m}$ Millipore cellulose ester membranes (previously washed with deionized water) and stored in polyethylene flasks at $-4^{\circ} \mathrm{C}$ for later DOC analyses. Chlorophyll- $a$ (ChL.), total nitrogen (N-Total), ammonium nitrogen $\left(\mathrm{N}-\mathrm{NH}_{4}\right)$, total phosphorous (P-Total) and phosphate $\left(\mathrm{P}-\mathrm{PO}_{4}\right)$ were later determined respectively according to Golterman et al. (30), Bergamin et al. (9), Giné et al. (29), Mackereth et al. (33) and Golterman et al. (30). For bacterioplankton analyses, samples were fixed with a formaldehyde borate buffered solution in a 
9:1 v/v proportion with final formaldehyde concentration of $2 \%$.

DOC was determined by using a TOC-V-CPH equipment (Shimadzu). The fluorescence spectroscopy analyses were made with an F-4500 fluorometer (Hitachi), with 240nm. $\mathrm{min}^{-1}$, $5 \mathrm{~nm}$ slit, $1 \mathrm{~cm}$ quartz cuvete and Milli-Q water as the blank. Emission spectra from 300 to $600 \mathrm{~nm}$ were obtained with excitation wavelengths of 370 and $314 \mathrm{~nm}$. Syncronous spectra were obtained from 250 to $600 \mathrm{~nm}$ with a wavelength interval $(\Delta \lambda)$ of $18 \mathrm{~nm}$. The UV-VIS spectroscopy analyses were made with wavelengths from 250 to $650 \mathrm{~nm}$ with a Carry 50 spectrophotometer (Varian). Two spectroscopic indexes were used (Table 1): E3/E4, which is inversely proportional to the degree of humification $(4 ; 15)$ and FR, which indicates whether DOC is from autochtonous or allochtonous sources $(35 ; 57 ; 58)$; and the direct measure of S298 (fluorescence intensity in the excitation/emission wavelengths 280/298), which indicates the presence of authochnous DOC structures $(27 ; 38)$.

Table 1. Spectroscopical indexes calculation.

\begin{tabular}{ccc}
\hline Index & Calculation & References \\
\hline E3/E4 & $\frac{E 3}{E 4}=\frac{A b s .(300 \mathrm{~nm})}{A b s .(400 \mathrm{~nm})}$ & $(4 ; 15)$ \\
& Abs. $=$ Absorptivity & $(35 ; 57 ; 58)$ \\
FR & $F R=\frac{F I(E m: 450 \mathrm{~nm} / \mathrm{Ex}: 370 \mathrm{~nm})}{F I(E m: 500 \mathrm{~nm} / \mathrm{Ex}: 370 \mathrm{~nm})}$ & \\
\hline
\end{tabular}

Bacterioplankton density was estimated through epyfluorescence using an Olympus BX51 microscope. Slides were prepared with $0.2 \mathrm{~mL}$ of fixed samples colored with $1 \mathrm{~mL}$ of $4,6^{\prime}-$ diamidino-2-phenyl-indole (DAPI; 39) $0.1 \%$ for 15 minutes in polycarbonate black (colored with Irgalan black) membranes with a $0.2 \mu \mathrm{m}$ pore (Wathman). The cells were counted in groups according to size and shape, and the biovolume of each shape was calculated according to Sun and Liu (49). Cell measurements were made in sample photographs with the Image-Pro Express image analyzer software, version 4.5.1.3 (Media Cybernetics, Inc.). To estimate biomass based on biovolume, the conversion factor of Thiel-Nielsen and Søndergaard (50) $\left(1 \mu \mathrm{m}^{3}=105 \mathrm{fg}\right.$ C) was used. Of helical cells, rare in the counting, no measurements were made, and the biomass was calculated using the Lee and Fuhrman (31) conversion factor. $(1$ cel. $=20 \mathrm{fg} \mathrm{C})$.

In order to observe differences between dry and rainy periods, determined by the amount of rain in the 15 preceding days to the sampling, considering biotic and abiotic variables, a T-test was used. To verify the influence of abiotic variables in density, biovolume and biomass of bacterioplankton, a Principal Components Analysis (PCA) was used to abiotic data (log, except $\mathrm{pH}$ ) ordination, with the axis selection made through Broken Stick criteria. After ordination, analysis of variance was made in order to check separation between periods. Also, a linear regression was made with scores and bacterioplankton features. Data ordination was performed with pcOrd software version 4.1 (34), and statistical analyses were made with Statistic version 7.0 (47).

\section{RESULTS}

Bacterioplankton densities varied between $1.3 \pm 0.710^{9} \mathrm{cel}^{-1}$ and 22.0 $\pm 4.710^{9} \mathrm{cel}^{-1}$. The highest values were found in SEP_08 sampling, when density was up to one order of magnitude higher than in other samples (Fig. 2a). Osmar lagoon showed the greatest variation, between $6.0 \pm 0.710^{9} \mathrm{cel} \mathrm{l}^{-1}$ and $22.0 \pm 4.710^{9}$ cel $1^{-1}$. 
Garças lagoon showed the lowest variation among sampling, between $6.2 \pm 1.010^{9} \mathrm{cel}^{-1}$ and $17.2 \pm 0.610^{9} \mathrm{cel}^{-1}$. The lowest

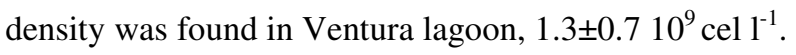

Bacterial biomass values varied between $0.22 \pm 0.3 \mathrm{mgC}^{-1}$ and $1.91 \pm 0.56 \mathrm{mgC}^{-1}$ (Fig. 2b). The highest values were found in SEP_08 sampling, together with the highest density values. The lagoon which showed the lowest variation in biomass was Guaraná, with values from $0.5 \pm 0.08 \mathrm{mgC}^{-1}$ to $0.91 \pm 0.18 \mathrm{mgC}^{-1}$. Garças and Osmar lagoons showed the highest seasonal variation, with values between $0.35 \pm 0.06 \mathrm{mgC}$ $\mathrm{l}^{-1}$ and $1.91 \pm 0.56 \mathrm{mgC}^{-1}$.

The biovolume varied between $0.08 \pm 0.01 \mu^{3}$ and $0.28 \pm 0.26 \mu^{3}$, considering average biovolume to all morphotypes of each lagoon. Regarding each morphotype, biovolumes varied between $0.04 \mu \mathrm{m}^{3}$ for small coccus and 0.29 $\mu \mathrm{m}^{3}$ for big rods, with little variation among lagoons and sampling.

The relative importance of different shapes in biomass and density varied little among sampling (Fig. 3), with coccus being the main form in all of them. The only one exception was Garças lagoon in FEB_08, where rods were the most abundant form.

The water level did not show great floods or long dry periods, but there was a high water peak between FEB_08 and JUN_08 sampling (Fig. 4a). The rain was more intense in the period before (sum of the 15 preceding days) the first two sampling (Fig. 4b).
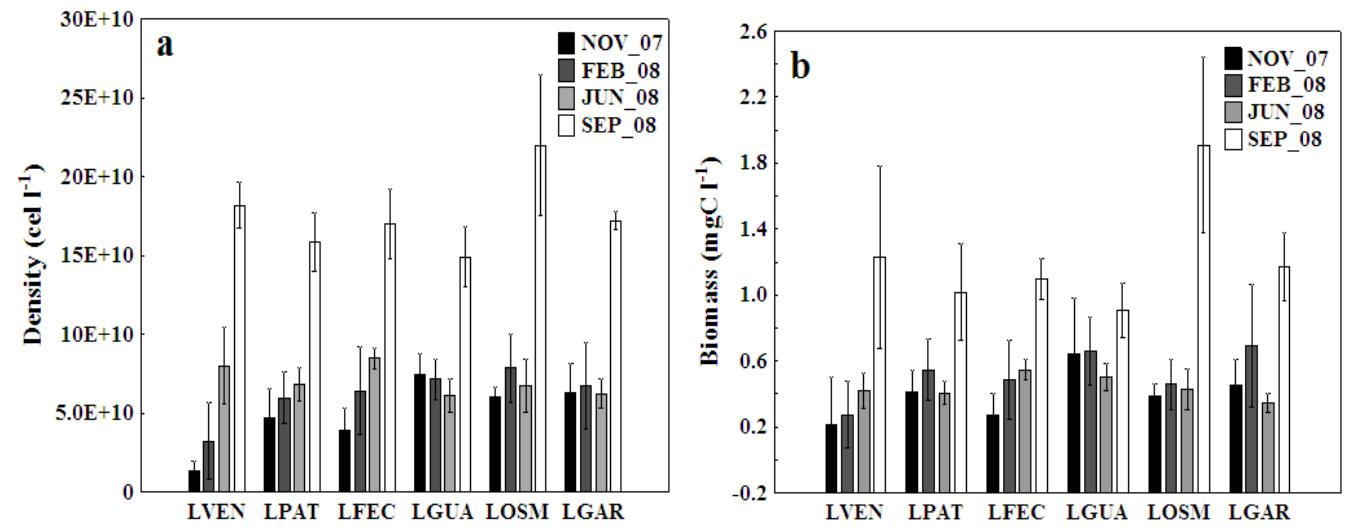

Figure 2. Bacterial density (a) and biomass (b) values (mean \pm standard deviation) in the lagoons Ventura (LVEN), Patos (LPAT), Fechada (LFEC), Guaraná (LGUA), Osmar (LOSM) and Garças (LGAR), in November 2007 (NOV_07), February, June and September 2008 (FEB_08, JUN_08, SET_08).
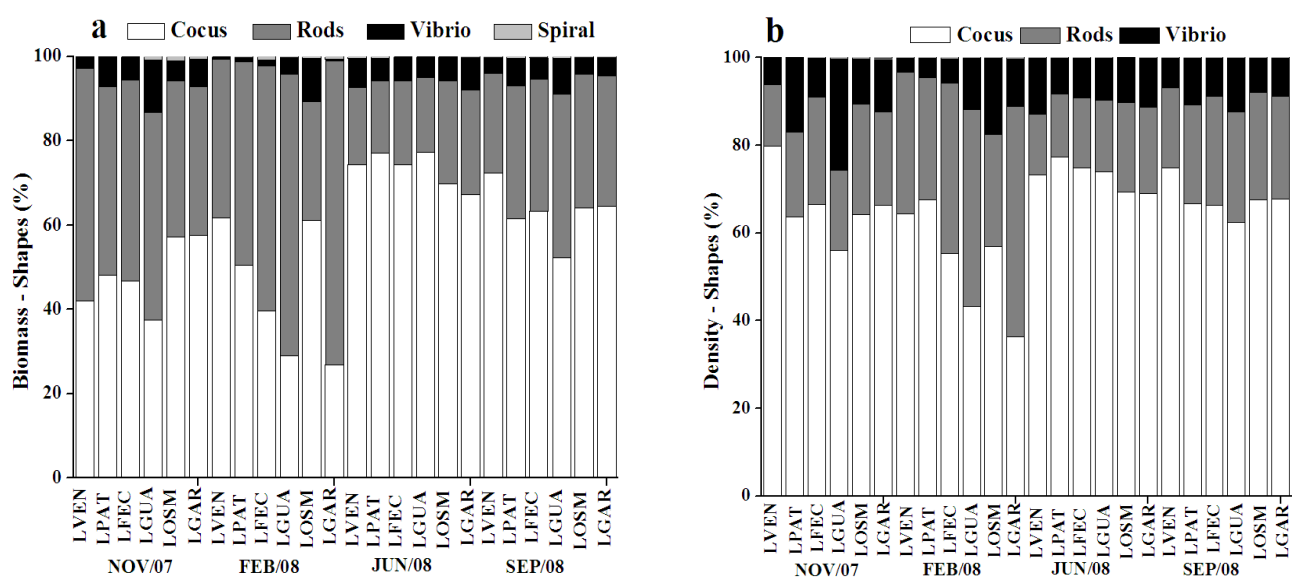

Figure 3. Relative biomass (a) and density (b) of different cell shapes in lagoons Ventura (LVEN), Patos (LPAT), Fechada (LFEC), Guaraná (LGUA), Osmar (LOSM) e Garças (LGAR) in November 2007 (NOV_07), February, June and September 2008 (FEB_08, JUN_08, SET_08). 

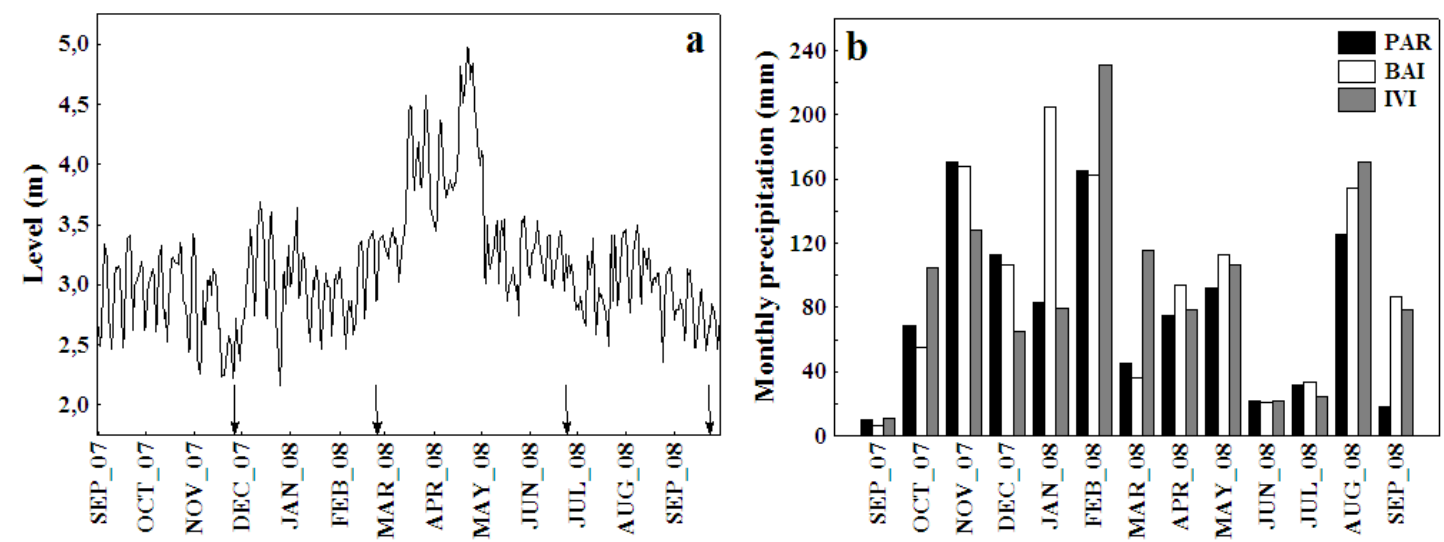

Figure 4. Hydrometric level of Paraná River (a) and monthly precipitation in the weather stations in Paraná (PAR), Baia (BAI), and Ivinheima (IVI) rivers. Arrows indicate sampling dates.

Most abiotic variables, Chl. and bacterioplankton density were significantly different $(p<0.05$; Table 2$)$ in the rainy and dry periods. In the rainy season (RS), NOV_07 and FEB_08 sampling, the temperatures were higher and dissolved oxygen (OD) concentrations were lower. Conductivity and $\mathrm{pH}$ values did not show significant variation. Secchi values indicated a greater water transparency in the dry season (DS), JUN_08 and SEP_08, along with lower values of Chl, N-Total, N-NH $\mathrm{N}_{4}, \mathrm{P}-$ Total and $\mathrm{P}_{-} \mathrm{PO}_{4}$. S298 was higher to DS samples, indicating a greater proportion of autochthonous DOC in these samples. FR and $\mathrm{E}_{3} / \mathrm{E}_{4}$, and DOC itself did not vary significantly.

Table 2. Mean and standard deviation (in parenthesis) and difference (T-test) between limnological variables in rainy and dry seasons, considering all lakes.

\begin{tabular}{|c|c|c|c|c|}
\hline & $\begin{array}{c}\text { Rainy Season } \\
\text { (Nov/Feb) }\end{array}$ & $\begin{array}{c}\text { Dry Season } \\
\text { (Jun/Sep) }\end{array}$ & $t$ & $\mathbf{P}$ \\
\hline Temperature $\left({ }^{\circ} \mathrm{C}\right)$ & $28.13 \quad(0.90)$ & 19.58 (1.66) & 15.67 & 0.00 \\
\hline $\mathrm{DO}\left(\mathrm{mg} \mathrm{l}^{-1}\right)$ & $4.87 \quad(1.67)$ & 7.38 (0.94) & -4.55 & 0.00 \\
\hline $\mathrm{pH}$ & $6.56(0.51)$ & $6.50(0.52)$ & 0.29 & 0.77 \\
\hline Conductivity $\left(\mu \mathrm{S} \mathrm{cm}^{-1}\right)$ & $45.60(12.23)$ & $36.86(14.15)$ & 1.62 & 0.12 \\
\hline Alkalinity $\left(\mathrm{mEq} \mathrm{1} \mathrm{l}^{-1}\right)$ & $273.10 \quad(114.44)$ & 269.78 (120.95) & 0.07 & 0.95 \\
\hline Secchi (m) & $0.38 \quad(0.18)$ & $0.65 \quad(0.32)$ & -2.63 & 0.02 \\
\hline $\operatorname{Chl}\left(\mu \mathrm{g} \mathrm{l}^{-1}\right)$ & $18.04(17.72)$ & $6.01 \quad(5.18)$ & 2.26 & 0.03 \\
\hline N-Total $\left(\mu \mathrm{g} \mathrm{l}^{-1}\right)$ & $1564.25 \quad(1274.58)$ & $676.81 \quad(392.27)$ & 2.31 & 0.03 \\
\hline $\mathrm{N}-\mathrm{NH}_{4}\left(\mu \mathrm{g} \mathrm{l}^{-1}\right)$ & $26.37(20.20)$ & $9.26(6.94)$ & 2.77 & 0.01 \\
\hline P-Total $\left(\mu \mathrm{g} \mathrm{l}^{-1}\right)$ & $114.18 \quad(72.65)$ & $58.85 \quad(34.45)$ & 2.38 & 0.03 \\
\hline $\mathrm{P}-\mathrm{PO}_{4}\left(\mu \mathrm{g}^{-1}\right)$ & $30.73(25.09)$ & $9.06 \quad(4.58)$ & 2.94 & 0.01 \\
\hline $\operatorname{DOC}\left(\mathrm{mg} \mathrm{l}^{-1}\right)$ & 7.15 (3.61) & $10.59(8.92)$ & -1.24 & 0.23 \\
\hline $\mathrm{E}_{3} / \mathrm{E}_{4}$ & 3.09 (0.79) & $3.12(0.75)$ & -0.08 & 0.94 \\
\hline FR & $1.82(0.29)$ & $1.65(0.14)$ & 1.87 & 0.07 \\
\hline S298 (au) & $13.46(4.82)$ & $38.02(10.12)$ & -7.59 & 0.00 \\
\hline Density $\left(10^{9} \mathrm{cel} \mathrm{l}^{-1}\right)$ & $5.62(1.96)$ & $12.05 \quad(5.37)$ & -3.90 & 0.00 \\
\hline Biomass $\left(\mathrm{mgC}^{-1}\right)$ & $0.47 \quad(0.16)$ & $0.78 \quad(0.39)$ & -2.53 & 0.02 \\
\hline Level (m) & $2.84 \quad(0.39)$ & $2.90 \quad(0.28)$ & -0.42 & 0.68 \\
\hline Rain (mm) & $72.60 \quad(41.54)$ & $31.80 \quad(34.27)$ & 2.62 & 0.02 \\
\hline
\end{tabular}


In the data ordination through PCA the three first axes explained $63.7 \%$ of the total data variance (Fig. 5a,b,c). The first axis $(25.7 \%)$ showed significant positive correlation with $\mathrm{E}_{3} / \mathrm{E}_{4}, \mathrm{~N}-\mathrm{Total}$ and DOC, and negative correlation with Secchi, inorganic carbon (IC) and total suspended material (TSM). The second axis (21.9\%) showed significant positive correlation with $\mathrm{NH}_{4}$ and $\mathrm{PO}_{4}$, and negative with Secchi and S298. The variables FR and S298 showed positive and negative correlation, respectively, with the third axis (16.1\%). The PCA scores were separated by the second axis according to rainy and dry seasons (Fig. 5a), with the first being characterized by higher dissolved nutrients concentration and the second by more transparent waters. The scores from RS and DS were significantly different (ANOVA, Fig. 5d).
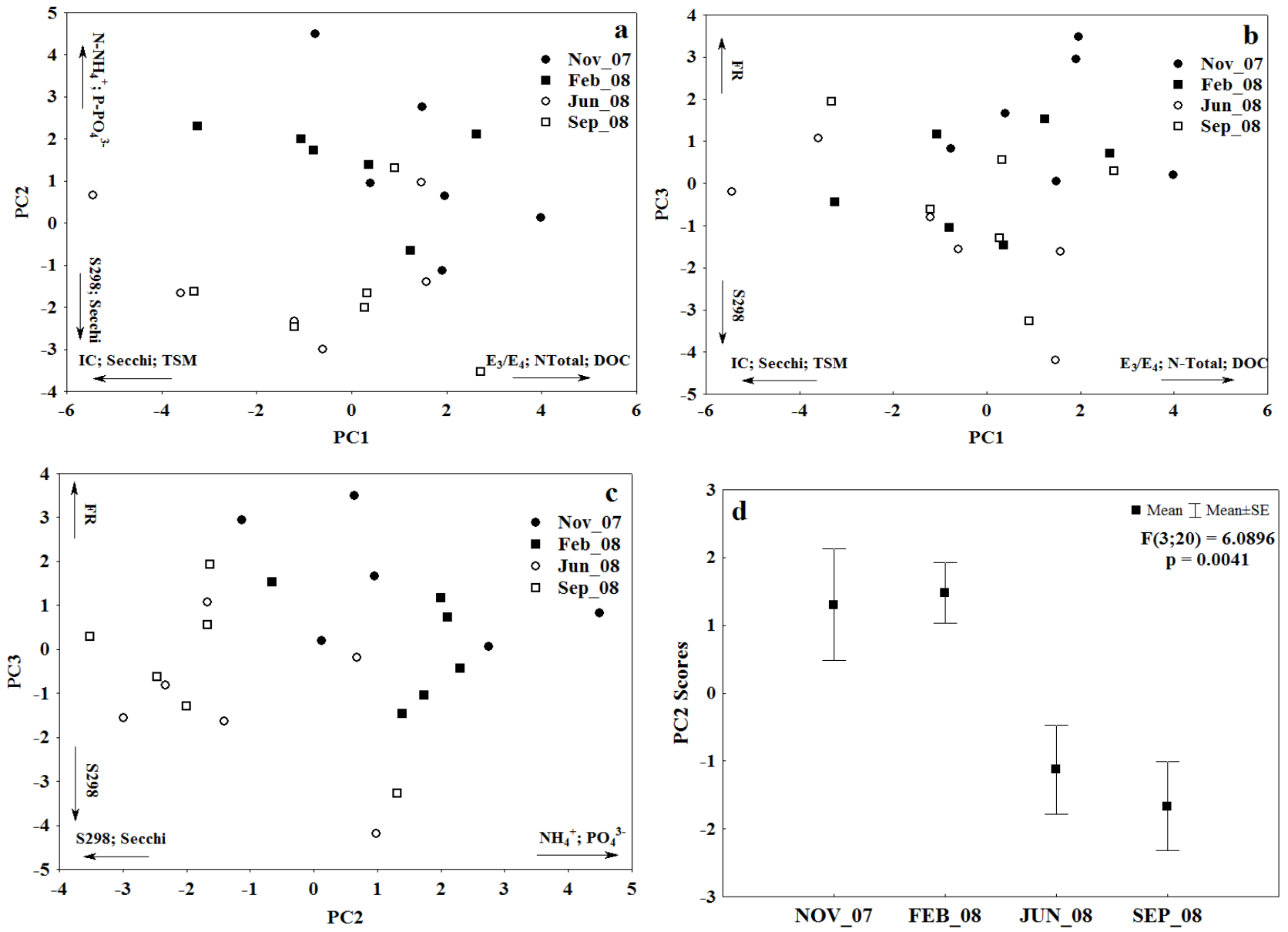

Figure 5. Scores distribution in the main axis one and two (a), two and three (b) and one and three (c). The variables that are correlated with the axis are indicated over the arrows. (d) ANOVA showing significant difference between rainy (November/2007 and February/2008) and dry seasons (June and September/2008).

The correlation between the bacterioplankton density and the PCA second axis was significant (Fig. 6a), indicating that the variables related to the second axis can explain $25 \%\left(r^{2}=0.250\right)$ of density data variability. Considering that the correlation was negative, the variables $\mathrm{N}-\mathrm{NH}_{4}$ and $\mathrm{P}-\mathrm{PO}_{4}$ affected density data negatively, while S298 and Secchi had a positive influence. The biomass showed a similar correlation with the second axis $\left(r^{2}=0,232\right)$, probably because these variables are correlated between themselves (biomass is calculated from density and biovolume data). 
Biovolume had a positive correlation with the third axis (Fig. 6b), which explained $17 \%\left(r^{2}=0.170\right)$ of data variability.
The variables that correlated with biovolume were FR, positively and S294, negatively.

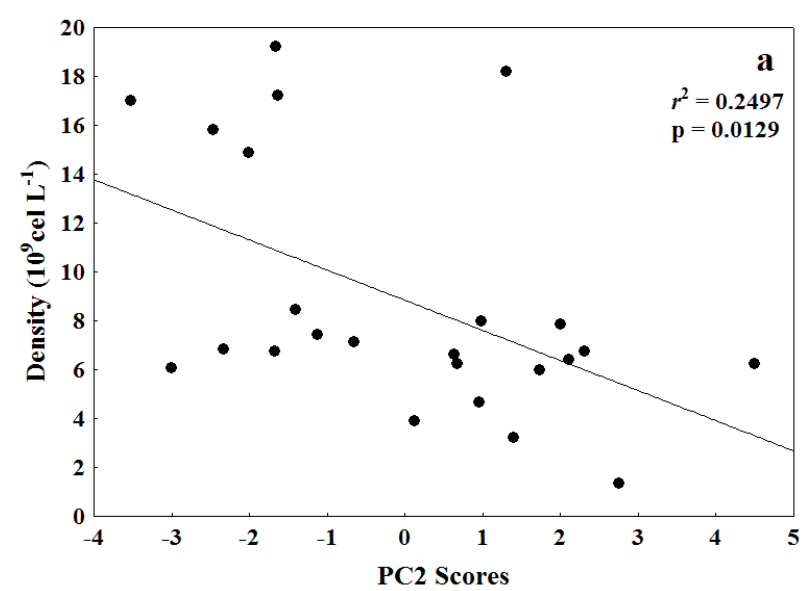

\section{DISCUSSION}

The density values found can be considered high. Carvalho et al. (14) found maximum density values of $5.810^{9}$ cel $1^{-1}$ in the same floodplain. In other floodplains, Rejas et al.

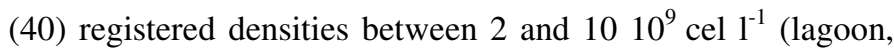
Ichilo River, Cochabamba, Bolívia) and Farjalla et al. (26) observed values in the magnitude of $10^{9} \mathrm{cel} \mathrm{l}^{-1}$ (Batata lagoon, Amazonas, Brazil).

Biomass values can also be considered high, with a mean value of $0.58 \pm 0.37 \mathrm{mgC}^{-1}$. Araújo and Godinho (3) found in Jequiti lagoon (Rio Grande do Norte, Brazil) biomass values of $0.27 \mathrm{mgC}^{-1}$ for maximum densities of $5010^{9} \mathrm{cel} \mathrm{l}^{-1}$. These authors used the equation proposed by Simon and Azam (46) to calculate biomass, while in this study the Thiel-Nielsen and Søndergaard (50) factor was used. Converting the values, the mean found for this study gets closer to the one found in

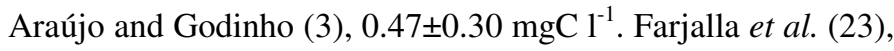
using the conversion factor proposed by Fry (1988), approximately 3 times higher than the one used in this study, found values between 0.45 and $14.32 \mathrm{mgC}^{-1}$ in coastal lagoons (Rio de Janeiro, Brazil), while the mean value of this study calculated by this factor is $1.69 \pm 1.09 \mathrm{mgC}^{-1}$.

Regarding cell biovolume, Araújo and Godinho (3) cited many studies made in continental waters with values from 0.05 to $0.53 \mu \mathrm{m}^{3}$, range in which the values from this study fit.

The coccus shape was more abundant in all sampling and environments, except in Garças lagoon in FEB_08. Araújo and Godinho (3) found predominance of rod shaped bacteria in almost all their sampling, with the second most abundant being coccus. Farjalla et al. (23) found predominance of rods in the lagoons with higher salinity, representing up to $90 \%$ of density. In the lagoons with lower salinity the shapes were more equally distributed, but rods were always the most abundant, followed by vibrio (23). In this study vibrio shape never represented more than $25 \%$ of density.

According to Sigee (45), the shape and size of cells can be related to nutrients availability in the system, because the variation in the surface/volume ratio $(\mathrm{S} / \mathrm{V})$ implies directly in the capacity of nutrients absorption. Taking this into account, the predominance of coccus cells can indicate that there is no nutrients limitation in the studied environments, for this shape has the lowest $\mathrm{S} / \mathrm{V}$ ratio. On the other hand, the same author points out the occurrence of inactive small coccus shaped cells 
when the environment shows unfavorable conditions. These cells cannot be differentiated in the counting, and if they represented a big amount of coccus shaped cells then there probably is bacterioplankton limitation by nutrients. The higher density of rods in Garças and Guaraná lagoons in FEB_08 can also show a nutrient limitation, which would favor a shape with higher S/V ratio.

Usually, the studies carried in Paraná River floodplain relate all kinds of data variation with the flood pulses (eg. 14), however, Rocha and Thomaz (42) showed that in the absence of a big flood, the rain becomes the main factor determining the features of the floodplain environments.

The highest values of N-Total, P-Total e $\mathrm{P}_{-} \mathrm{PO}_{4}$ found in NOV_07 and FEB_08 sampling can indicate that the rain carried soil nutrients into water bodies, what would also explain the higher turbidity found in these sampling. The segregation between DS and RS through the PCA also showed that in rainy periods dissolved nutrients concentration raised. In the DS transparency was higher and so was S298, showing the predominance of autochtonous carbon $(7 ; 27 ; 38)$.

The negative influence of dissolved nutrients concentration $\left(\mathrm{N}-\mathrm{NH}_{4}\right.$ and $\left.\mathrm{P}-\mathrm{PO}_{4}\right)$ on density and biomass can indicate competition, because these conditions would increase phytoplankton development. According to some authors (16; 19), bacterioplankton is more efficient in assimilating nutrients in low concentrations, and in a rich environment it could be suppressed by phytoplankton growth. That being considered, it is possible that competition with phytoplankton is the reason why the dissolved nutrients had a negative influence on density and biomass. However, it is worth noting that the points that most influenced this correlation were from SEP_08 sampling, a low rain and hydrometric levels period, conditions when the highest phytoplankton densities usually occur (43).

Despite the lack of studies relating bacterioplankton features directly with spectroscopic measurements of DOC, some discuss its relation with the humification degree of the environments measured by others means. Tranvik (55) evaluated DOC with different contents of humic compounds in its capacity to support bacterial growth. He concluded that humic and non humic environments have DOC equally available to bacterioplankton. This way, the higher concentration of DOC in humic environments would imply in a greater support capacity, even considering the lower availability of primary production DOC, limited by the dark water. More recent studies diverge regarding autochthonous or allochtonous DOC utilization by bacterioplankton. Carrilo et al. (13) observed an increase in bacterioplankton production due to a raise in algal exudates liberation, caused by an increment in UV radiation, indicating the importance of primary production DOC to bacterioplankton. However, Daniel et al. (21) demonstrated that in the absence of recent algal DOC the microbial loop keeps transferring energy to metazooplankton. In Paraná River floodplain, Carvalho et al. (14) did not find any relation between Chl. and bacterioplankton, concluding that this community uses mainly allochthonous DOC. Considering the positive relation of density and biomass with S298 and Secchi, but not with phytoplankton production (represented by Chl. and $\mathrm{P}-\mathrm{PO}_{4}$ ), it is probable that the labile carbon being used by this community is from aquatic macrophytes decomposition.

Biovolume showed a positive correlation with FR and negative with S298, indicating that even in the absence of more labile carbon bacterioplankton can increase its size. Despite both FR and S298 being directly proportional to humification degree, FR is a more general index. S298 indicates the presence of simple molecules, which Azevedo et al. (6) considered from aquatic macrophytes decomposition. The negative relation between biovolume, which is directly proportional to biomass, and S298 indicates that in more humic environments cells were larger. Tranvik and Höfle (56) found a similar relation in an experiment on bacterial growth where higher (double) values of biomass were found in cultures prepared with humic water. 


\section{CONCLUSION}

The bacterioplankton community characterization in terms of biomass, density and biovolume showed that the environments of the floodplain have similarities with other freshwater environments. Bacterial community features varied in time, with higher density and biomass values in the dry period. The limnological and spectroscopic features that showed any relation with bacterioplankton were $\mathrm{N}_{-} \mathrm{NH}_{4}, \mathrm{P}-$ $\mathrm{PO}_{4}$, transparency, $\mathrm{S} 298$ and FR. The analysis of these relations suggested that i) the lower bacterioplankton densities found in the rainy season were not due to nutrients limitation; ii) in the dry period the DOC available to bacterioplankton is more labile, however it is probably from aquatic macrophytes and not from phytoplankton; iii) in general, the presence of more labile carbon resulted in higher bacterioplankton densities and biomass.

\section{AKNOWLEDGEMENTS}

We thank Maria do Carmo Roberto (Maringá State University) for field assistance and nutrients analysis. M. Teixeira and N. Santana were provided with CAPES (Coordenação de Aperfeiçoamento de Pessoal de Nível Superior) scholarships. This study was also supported by the “Long-Term Ecological Research" (LTER) program of CNPq (Brazilian Council of Research).

\section{REFERENCES}

1. Amado, M.A.; Farjalla, V.F.; Esteves, F.A.; Bozelli, L.R.; Roland, F.; Enrich-Prast, A. (2006). Complementary pathways of dissolved organic carbon removal pathways in clear-water Amazonian ecosystems: photochemical degradation and bacterial uptake. FEMS Microbiol Ecol, 56 (1), 8-17.

2. Amon, R.M.R.; Benner, R. (1996). Photochemical and microbial consumption of dissolved organic carbon and dissolved oxygen in the Amazon River system. Geochim Cosmochim Acta, 60 (10), 1783-1792.

3. Araújo, M.F.F.; Godinho, M.J. (2008). Seasonal and spatial distribution of bacterioplankton in a fluvial-lagunar system of a tropical region: density, biomass, cellular volume and morphologic variation. Braz Arch Biol Technol, 51 (1), 203-212.

4. Artinger, R.; Buckaua, G.; Geyerb, S.; Fritz, P.; Wolfc, M.; Kim, J.I. (2000). Characterization of groundwater humic substances: influence of sedimentary organic carbon. Appl Geochem, 15, 97-116.

5. Azam, F.; Fenchel, T.; Fiel, J.G.; Gray, J.S.; Meyer-Rell, L.A.; Thingstad, F. (1983). The ecological role of water-column microbes in the sea. Mar Ecol Prog Ser, 19 (3), 257-263.

6. Azevedo, J.C.R.; Mizukawa, A.; Teixeira, M.C.; Pagioro, T.A., (2008a). Contribuição da decomposição de macrófitas aquáticas (Eichhornia azurea) na matéria orgânica dissolvida. Oecol Bras, 12 (1), 42-56.

7. Azevedo, J.C.R.; Teixeira, M.C.; Dos Santos, A.M.; Leandrini, J.A.; Pagioro, T.A. (2008b). Caracterização espectroscópica da matéria orgânica dissolvida da planície de inundação do alto rio Paraná. Oecol Bras, 12 (1), 66-77.

8. Baines, S.B.; Pace, M.L. (1990). The production of dissolved organic matter by phytoplankton and its importance to bacteria: Patterns across marine and freshwater systems. Limnol Oceanogr, 36 (6), 1078-1090.

9. Bergamin, H.; Reis, B.F.; Zagatto, E.A.G. (1978). A new device for improving sensitivity and stabilization in flow injection analysis. Anal Chim Acta, 97, 427-431.

10. Bianchini Jr., I.; Cunha-Santino, M.B. (2008). As rotas de liberação do carbono dos detritos de macrófitas aquáticas. Oecol Bras, 12 (1), 20-29.

11. Carlson, C.A.; Ducklow, H.W. (1996). Growth of bacterioplankton and consumption of dissolved organic carbon in the Sargasso Sea. Aquat Microb Ecol, 10, 69-85.

12. Carmouze, J.P. (1994). O metabolismo dos ecossistemas aquáticos: fundamentos teóricos, métodos de estudo e análises químicas. Edgar Blucher/SBL/FAPESP, São Paulo.

13. Carrilo, P.; Medina-Sánchez, J.M.; Villar-Argaiz, M. (2002). The interaction of phytoplankton and bacteria in a high mountain lake: Importance of the spectral composition of solar radiation. Limnol Oceanogr, 47 (5), 1294-1306.

14. Carvalho, P.; Thomaz, S.M.; Bini, L.M. (2003). Effects of water level, abiotic and biotic factors on bacterioplâncton abundance in lagoons of a tropical floodplain (Paraná River, Brazil). Hydrobiologia, 510, 67-74.

15. Chen, J.; Leboeuf, E.J.; Dai S.; Gu, B. (2002). Spectroscopic characterization of the structural and functional properties of natural organic matter fractions. Chemosphere, 48, 59-68.

16. Cobeney, M.F.; Wetzel, R.G. (1991). Effects of nutrients on specific growth rate of bacterioplankton in oligotrophic lake water cultures. Appl Environ Microbiol, 58, 150-156.

17. Cole, J.J.; Findlay, S.; Pace, M.L. (1988). Bacterial production in fresh and saltwater ecosystems: a cross-system overview. Mar Ecol Prog Ser, 43, 1-10.

18. Cotner, J.B.; Biddanda, B.A. (2002). Small players, large role: microbial influence on biogeochemical processes in pelagic aquatic ecosystems. 
Ecosystems, 5 (2), 105-121.

19. Currie, D.J.; Kalff, J. (1984a). A comparison of the abilities of freshwater algae and bacteria to acquire and retain phosphorus. Limnol Oceanogr, 29 (2), 298-310.

20. Currie, D.J.; Kalff, J. (1984b). The relative importance of bacterioplankton and phytoplankton in phosphorus uptake in freshwater. Limnol Oceanogr, 29 (2), 311-321.

21. Daniel, C.; Gutseit, K.; Anesio, A.M.; Granéli, W. (2005). Microbial food webs in the dark: independence of lake plankton from recent algal production. Aquat Microb Ecol, 38 (2), 113-123.

22. Faria, B.M.; Esteves, F.A. (2001). Dissolved organic carbon in two Brazilian coastal lagoons: sources and utilization for heterotrophic bacteria. In: Faria, B.M.; Farjalla, V.F.; Esteves, F.A. (eds). Aquatic Microbial Ecology in Brazil. Series Oecologia Brasiliensis, vol. IX, PPGE-UFRJ, Rio de Janeiro, Brasil, p. 57-64.

23. Farjalla, V.F.; Faria, B.M.; Esteves, F.A.; Bozelli, R.L. (2001a). Bacterial density and biomass, and relations with abiotic factors, in 14 coastal lagoons of Rio de Janeiro state. In: Faria, B.M.; Farjalla, V.F.; Esteves, F.A. (eds). Aquatic Microbial Ecology in Brazil. Series Oecologia Brasiliensis, vol. IX, PPGE-UFRJ, Rio de Janeiro, Brasil, p. 65-76.

24. Farjalla, V.F.; Anesio, A.M.; Bertilsson, S.; Graneli, W. (2001b). Photochemical reactivity of aquatic macrophytes leachates: abiotic transformations and bacterial response. Aquat Microb Ecol, 24, 187-195.

25. Farjalla, V.F.; Azevedo, D.A.; Esteves, F.A.; Bozelli, R.L.; Roland F.; Enrich-Prast, A. (2006a). Influence of hydrological pulse on bacterial growth and DOC uptake in a clear-water Amazonian lake. Microb Ecol, 52 (2), 334-344.

26. Farjalla, V.F.; Enrich-Prast, A.; Esteves, F. A.; Cimbleiris, A.C.P. (2006b). Bacterial growth and DOC consumption in a tropical coastal lagoon. Braz J Biol, 66 (2a), 383-392.

27. Ferrari, G.; Mingazzini, M. (1995). Synchronous fluorescence spectra of dissolved organic matter of algal origin in marine coastal waters. Mar Ecol Prog Ser, 125, 305-315.

28. Gasol, J.M.; Duarte, C.M. (2000). Comparative analyses in aquatic microbial ecology: how far do they go? FEMS Microbiol Ecol, 31 (2), 99-106.

29. Giné, M.F.; Bergamin, F.H.; Zagatto, E.A.G.; Reis, B.F. (1980). Simultaneous determination of nitrate and nitrite by flow injection analysis. Anal Chim Acta, 114, 191-197.

30. Golterman, H.L.; Clymo, R.S.; Ohmstad, M.A.M. (1978). Methods for physical and chemical analysis of fresh water. Blackwell Scientific, Oxford.

31. Lee, S.; Fuhrman, J.A. (1987). Relationships between biovolume and biomass of naturally-derived marine bacterioplankton. Appl Environ Microbiol, 52, 1298-1303.

32. Lovley, D.R.; Coates, J.D.; Blunt-Harris, E.L.; Phillips, J.P.; Woodward,
J.C. (1996). Humic substances as electron acceptors for microbial respiration. Nature, 382, 445-448.

33. Mackereth, F.Y.H., Heron, J.; Talling, J.J. (1978). Water analysis: some revised methods for Limnologists. Freshwater Biological Association, Ambleside.

34. McCune, B.; Mefford, M.J. (1999). PC-ORD. Multivariate analysis of ecological data, version 4.01. MJM Software Design Gleneden Blach, Oregon .

35. McKnight, D.M.; Boyer, E.W.; Westerhoff, P.K.; Doran, P.T.; Kulbe, T.; Andersen, D.T. (2001). Spectrofluorometric characterization of dissolved organic matter for indication of precursor organic material and aromaticity. Limnol Oceanogr, 46 (1), 38-48.

36. Morris, D.P.; Lewis Jr., W.M. (1992). Nutrient limitation of bacterioplankton growth in Lake Dillon, Colorado. Limnol Oceanogr, 37 (6), 1179-1192.

37. Patel-Sorrentino, N.; Mounier, S.; Lucas, Y.; Benaim, J.Y. (2004). Effects of UV-visible irradiation on natural organic matter from the Amazon basin. Sci Total Environ, 321 (1-3), 231-239.

38. Peuravuori, J.; Koivikko, R.; Pihlaja, K. (2002). Characterization, differentiation and classification of aquatic humic matter separated with different sorbents: synchronous scanning fluorescence spectroscopy. Water Res, 36 (18), 4552- 4562.

39. Porter, K.G.; Feig, Y.S. (1980). The use of DAPI for identifying and counting aquatic microflora. Limnol Oceanogr, 25 (5), 943-948.

40. Rejas, D.; Muylaert, K.; De-Meester, L. (2005). Phytoplanktonbacterioplankton interactions in a neotropical floodplain lake (Laguna Bufeos, Bolivia). Hydrobiologia, 543 (1), 91-99.

41. Roberto, M.C.; Santana, N.F.; Thomaz, S. M. (2009). Limnology in the Upper Paraná River floodplain: large-scale spatial and temporal patterns, and the influence of reservoirs. Braz J Biol, 69 (2), 717-725.

42. Rocha, R.R.A.; Thomaz, S.M. (2004). Variação Temporal de fatores limnológicos em ambientes da planície de inundação do alto rio Paraná (PR/MS - Brasil). Acta Sci Biol Sci, 26 (3), 261-271.

43. Rodrigues, L.C.; Train, S.; Bovo-Scomparin, V.M.; Jati, S.; Borsalli, C.C.J.; Marengoni, E. (2009). Interannual variability of phytoplankton in the main rivers of the upper Paraná River floodplain, Brazil: influence of upstream reservoirs. Braz J Biol, 69 (2), 501-516.

44. Roland, F.; Vidal, L.O. (2001). Heterotrophic bacterial respiration: a relevant measurement for the understanding of plankton metabolism. In: Faria, B.M.; Farjalla, V.F.; Esteves, F.A. (eds). Aquatic Microbial Ecology in Brazil. Series Oecologia Brasiliensis, vol. IX, PPGE-UFRJ, Rio de Janeiro, Brasil, p. 97-116.

45. Sigee, D.C. (2005). Freshwater microbiology: biodiversity and dynamic interactions of microorganisms in the freshwater environment. John Wiley and Sons Ldt, England.

46. Simon, M.; Azam, F. (1989). Protein content and protein synthesis rates of planktonic marine bacteria. Mar Ecol Prog Ser, 51, 201-213. 
47. Statsoft, InC. (2005). Statistica (data analysis software system). Version 7.1. www.statsoft.com.

48. Steinberg, C.E.W.; Kamara, S.; Prokhotskaya, V.Y.; Manusadzianas, L.; Karasyova, T.A.; Timofeyev, M.A.; Zhang, J.; Paul, A.; Meinelt, T.; Farjalla, V.F.; Matsuo, A.Y.; Burninson, B.K.; Menzel, R. (2006). Dissolved humic substances - ecological driving forces from the individual to the ecosystem level? Freshwater Biol, 51 (7), 1189-1210.

49. Sun, J.; Liu, D. (2003). Geometric models for calculating cell biovolume and surface area for phytoplankton. J Plankton Res, 25 (11), 1331-1346.

50. Thiel-Nielsen, J.; Søndergaard, M. (1998). Bacterial carbon biomass calculated from biovolumes. Arch Hydrobiol, 141 (2), 195-207.

51. Thomas, J.D. (1997). The role of dissolved organic matter, particularly free amino acids and humic substances, in freshwater ecosystems. Freshwater Biol, 38 (1), 1-36.

52. Thomaz, S.M.; Pagioro, T.A.; Bini, L.M.; Roberto, M.C.; Rocha, R.R.A. (2004). Limnology of the upper Paraná floodplain habitats: patterns of spatio-temporal variations and influence of the water levels. In: Agostinho, A.A.; Rodrigues, L.; Gomes, L.C.; Thomaz, S.M.; Miranda, L.E. (eds). Structure and functioning of the Paraná River and its floodplain. Eduem, Brasil. p. 37-42.

53. Thomaz, S.M.; Bini, L.M.; Bozelli, R.L. (2007). Floods increase similarity among aquatic habitats in river-floodplain systems. Hydrobiologia, 579 (1), 1-13.

54. Toolan, T.; Wehr, J.D.; Findlay, S. (1991). Inorganic phosphorus stimulation of bacterioplankton production in a meso-eutrophic lake. Appl Environ Microbiol, 57 (7), 2074-2078.

55. Tranvik, L.J. (1989). Bacterioplankton in humic lakes: a link between allochtonous organic matter and pelagic food webs. Lund, Sweden. (Doctoral Thesis. Lund University, Sweden).

56. Tranvik, L.J.; Höfle, M.G. (1987). Bacterial growth in mixed cultures on dissolved organic carbon from humic and clear waters. Appl Environ Microbiol, 56, 482-488.

57. Westerhoff, P.; Anning, D. (2000). Concentration and characteristics of organic carbon in surface water in Arizona: influence of urbanization. $J$ Hydrol, 236 (3), 202-222.

58. Wu, F.C.; Tanoue, E.; Liu, C.Q. (2007). Relationships between DOC concentrations, molecular size and fluorescence properties of DOM in a stream. Appl Geochem, 22, 1659-1667. 